\title{
inu \\ Catalytic Pyrolysis of High-Density Polyethylene: Decomposition Efficiency and Kinetics
}

\author{
Hadas Raveh-Amit ${ }^{1, *(\mathbb{D}}$, Florent Lemont ${ }^{2}$, Gabriela Bar-Nes ${ }^{1,3}$, Ofra Klein-BenDavid ${ }^{1,4}$, Nissim Banano ${ }^{1}$, \\ Svetlana Gelfer ${ }^{1}$, Patrice Charvin ${ }^{2}$, Tahriri Bin Rozaini ${ }^{2}$, Johann Sedan ${ }^{2}$ and François Rousset ${ }^{2}$ \\ 1 Department of Chemistry, Nuclear Research Centre Negev, P.O. Box 9001, Beer Sheva 8419000, Israel; \\ gabi.barnes@gmail.com (G.B.-N.); ofrak1@googlemail.com (O.K.-B.); nissoba@gmail.com (N.B.); \\ gelfersveta1973@gmail.com (S.G.) \\ 2 DES, ISEC, DE2D, SEVT, LPTI, CEA, Centre de Marcoule, BP17171, 30207 Bagnols sur Cèze, France; \\ florent.lemont@cea.fr (F.L.); Patrice.charvin@cea.fr (P.C.); Muhamad-Tahriri.BINROZAINI@cea.fr (T.B.R.); \\ Johann.Sedan@cea.fr (J.S.); francois.rousset@cea.fr (F.R.) \\ 3 Department of Civil and Environmental Engineering, Ben-Gurion University of the Negev, P.O. Box 653, \\ Beer-Sheva 8410501, Israel \\ 4 Department of Geological and Environmental Sciences, Ben-Gurion University of the Negev, P.O. Box 653, \\ Beer-Sheva 8410501, Israel \\ * Correspondence: hadasa@nrcn.gov.il; Tel.: +972-8656-7852
}

\section{check for} updates

Citation: Raveh-Amit, H.; Lemont, F.; Bar-Nes, G.; Klein-BenDavid, O.; Banano, N.; Gelfer, S.; Charvin, P.; Bin Rozaini, T.; Sedan, J.; Rousset, F. Catalytic Pyrolysis of High-Density Polyethylene: Decomposition Efficiency and Kinetics. Catalysts 2022, 12, 140. https://doi.org/ $10.3390 /$ catal12020140

Academic Editors: Laura Santamaria and Maite Artetxe

Received: 11 December 2021

Accepted: 19 January 2022

Published: 24 January 2022

Publisher's Note: MDPI stays neutral with regard to jurisdictional claims in published maps and institutional affiliations.

Copyright: (C) 2022 by the authors. Licensee MDPI, Basel, Switzerland. This article is an open access article distributed under the terms and conditions of the Creative Commons Attribution (CC BY) license (https:// creativecommons.org/licenses/by/ $4.0 /)$.

\begin{abstract}
Organic waste is generally characterized by high volume-to-weight ratios, requiring implementation of waste minimization processes. In the present study, the decomposition of high-density polyethylene (HDPE), was studied under thermal and catalytic pyrolysis conditions on two experimental systems. Firstly, pyrolytic conditions for HDPE decomposition were optimized in a laboratory-scale batch reactor. In order to maximize gas yields and minimize secondary waste, the effects of aluminosilicate catalysts, catalyst loading, and reaction temperature on decomposition efficiency were examined. Secondly, kinetics and reaction temperatures were studied on a large capacity thermobalance, especially adjusted to perform experiments under pyrolytic conditions at a larger scale (up to $20 \mathrm{~g}$ ). The addition of catalysts was shown to enhance polymer decomposition, demonstrated by higher gas conversions. Condensable yields could be further minimized by increasing the catalyst to polymer ratio from 0.1 to 0.2 . The most prominent reduction in pyrolysis temperature was obtained over ZSM- 5 catalysts with low Si/Al ratios; however, this impact was accompanied by a slower reaction rate. Of the zeolites tested, the ZSM- 5 catalyst with a Si/Al of 25 was found to be the most efficient catalyst for waste minimization and organic destruction, leading to high gas conversions ( $90 \mathrm{wt} \%$.) and a 30-fold reduction in solid waste mass.
\end{abstract}

Keywords: waste minimization; plastic decomposition; catalytic pyrolysis; zeolites; macro thermogravimetric analysis

\section{Introduction}

Organic waste is characterized by high volume to weight ratios, requiring implementation of waste minimization processes. When organic waste is contaminated with radionuclides, it may further pose a hazard due to radiolysis and the generation of combustible and explosive gases. Thus, minimizing waste volume as well as forming a chemically stable and conditioned matrix are of high importance in the treatment of contaminated polymers. Effective volume reduction of solid organic waste can be achieved by thermal treatments, such as incineration, gasification, pyrolysis and plasma treatments. Moreover, thermal treatments can improve the homogeneity and stability of the waste produced following treatment $[1,2]$.

Pyrolysis, i.e., the process of thermal decomposition of organics in the absence of oxygen, produces three main products: solid char, condensable oils and organic and 
inorganic gases [3]. The metal radionuclides are expected to remain in the char solid waste fraction and not to migrate into the condensable and gas fractions [1]. Pyrolysis has several key advantages over other thermal processes. Firstly, it is considered more environmentally compliant than incineration due to the limited carbon dioxide and significantly lower NOx and SOx levels emitted during the process. Secondly, unlike incineration treatment, pyrolysis is performed at moderate temperatures and thus, it is less challenging with respect to the volatilization of radionuclides.

Pyrolysis for solid organic waste contaminated with radionuclides has not been extensively studied, in contrary to the 30 years of research on the valorization of plastic waste into valuable fuels and chemicals [3-6]. This technology is considered promising for recovering non-recyclable plastics and obtaining valuable products [6]. Analysis of the thermo-gravimetric profiles, kinetic parameters and product composition of plastic pyrolysis was examined on various reactor types and for different waste compositions, of which high- and low-density polyethylene, polypropylene, and polystyrene have been mostly studied, as these polymers represent real-world plastic waste composition [6-8]. Such studies provided useful information on the decomposition mechanisms involved and on the optimization of olefins and aromatics product generation. Product selectivity and conversion yields can be enhanced by adding catalysts, i.e., catalytic pyrolysis. It also allows operating at lower reaction temperatures and, thus, lowering the energy consumption of these processes. Among the different catalysts, the ZSM-5 zeolite and Zeolite Y, are widely used in hydrocarbon cracking due to their acidity, pore structure, and thermal stability $[9,10]$. Product selectivity and conversion yields are also influenced by the reaction conditions, including temperature, heating rate, residence time in the reaction zone, and reactor type, as previously reviewed in detail [11].

Whereas product selectivity and the generation of valuable products are critical goals for the pyrolysis of municipal solid waste [6], it is not required for volume reduction of radioactively-contaminated plastics [1]. To be considered a suitable thermal treatment for the minimization of radio-contaminated organic waste, three main goals need to be met: (i) significantly reduce waste volume into char; (ii) minimize secondary waste and (iii) maximize gas yields. The first goal is set to concentrate all the refractory radionuclides in the char fraction. The two other goals are aimed to increase the treatable gas volume and decrease the complex condensed hydrocarbons, reducing the risk of blocking and scaling in the experimental system. Hu et al. studied the product conversion of typical solid wastes (polyethylene, paper towels, and textile) by thermal pyrolysis at different temperatures ranging from $475{ }^{\circ} \mathrm{C}$ to $550{ }^{\circ} \mathrm{C}$ [12]. Increasing the pyrolysis temperature resulted in increased conversions to gas $(\sim 20 \mathrm{wt} \%$ to $\sim 40 \mathrm{wt} \%)$ and decreased liquid yields $(\sim 60 \mathrm{wt} \%$ to $\sim 50 \mathrm{wt} \%$ ) when the mixed wastes were treated. Similar trends in product conversions were observed when polyethylene only was treated at identical reaction conditions. However, high liquid yields were produced (for polyethylene) at all temperatures tested. KleinBenDavid et al. studied polyethylene pyrolysis at different reaction temperatures up to $600{ }^{\circ} \mathrm{C}$ in order to reduce the liquid yields by maximizing the gas yields [13]. Even at the highest temperature tested, the wax and oil fractions could not be reduced to less than $\sim 35 \mathrm{wt} \%$ of the product yields. This study demonstrated that although the solid waste mass was effectively reduced (the char fraction was $\sim 1-2 \mathrm{wt} \%$ ), additional improvements are required to minimize condensable yields if pyrolysis is to be considered a suitable thermal treatment for the minimization of contaminated solid waste. The present study aims to fill this gap by examining the use of catalytic pyrolysis as a means to optimize product conversions for solid organic waste contaminated with radionuclides.

Here, polymer decomposition by catalytic pyrolysis was explored as a method for waste minimization for solid organic waste contaminated with radionuclides. Two types of catalysts were studied, Zeolite $\mathrm{Y}$ and ZSM-5, which were previously shown to enhance gas yields of the polymers pyrolyzed, regardless of the reactor type $[9,10]$. In the first set of experiments, the effects of different catalysts, reaction temperature and catalyst loading on decomposition efficiency were studied in order to optimize product conversions. In 
the second set of experiments, the impact of the catalysts on the reaction temperature and decomposition kinetics was studied on a large capacity thermobalance system, especially adjusted to perform experiments under pyrolytic conditions on up to $20 \mathrm{~g}$ of polyethylene.

\section{Results and Discussion}

\subsection{Impact of Aluminosilicate Catalysts and Reaction Temperature}

To study the catalytic effects on polymer decomposition, HDPE was treated by thermal (no catalyst) and catalytic pyrolysis at mild temperatures $\left(450^{\circ} \mathrm{C}\right.$ and $525^{\circ} \mathrm{C}$ ) in the presence of different catalysts (Table 1). A description of the pyrolysis system and a schematic diagram are presented in Section 3.2. Product conversions into gas, condensable, and char were calculated to evaluate the decomposition efficiency of the treatment. Product distribution of pyrolyzed HDPE following thermal and catalytic conditions performed at a reaction temperature of $450^{\circ} \mathrm{C}$ and $525^{\circ} \mathrm{C}$ are presented in Figures 1 and 2, respectively.

Table 1. Chemical and physical properties of catalysts used in this study.

\begin{tabular}{cccc}
\hline Catalyst & $\mathbf{S i O}_{\mathbf{2}} / \mathbf{A l}_{\mathbf{2}} \mathbf{O}_{\mathbf{3}}$ Ratio & Surface Area $\left[\mathbf{m}^{2} / \mathbf{g}\right]$ & Pore Radius $[\mathbf{n m}]$ \\
\hline Zeolite Y & 5.1 & 900 & 0.74 \\
ZSM-5 (25) & 25 & 425 & 0.56 \\
ZSM-5 (200) & 200 & 400 & 0.56 \\
ZSM-5 (800) & 800 & 405 & 0.56 \\
\hline
\end{tabular}

(a)

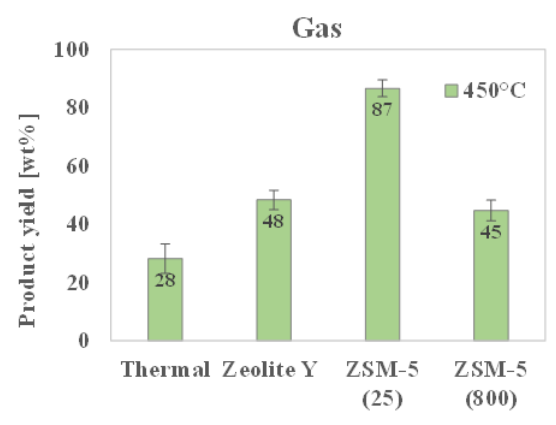

(b)

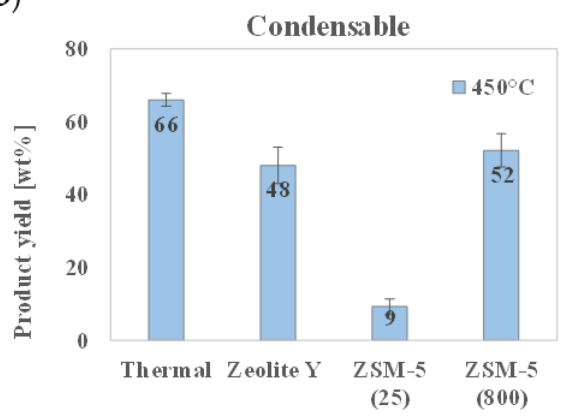

(c)

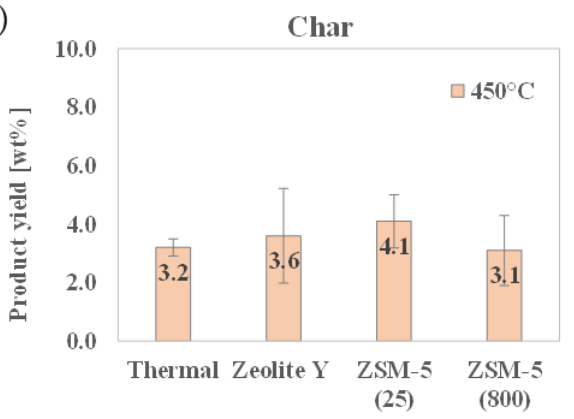

Figure 1. Product distribution following HDPE polymer decomposition in the presence of catalysts at $450{ }^{\circ} \mathrm{C}$. Si / Al ratios of the catalysts are depicted in brackets. (a) Gas yields. (b) Condensable yields. (c) Char yi elds. (Note: $y$-axis scale ranges are different). 
(a)

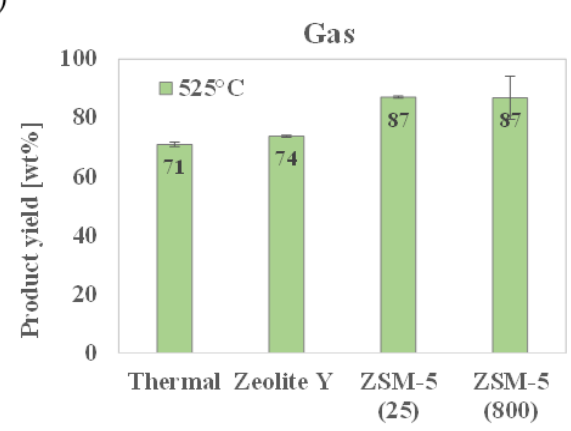

(b)

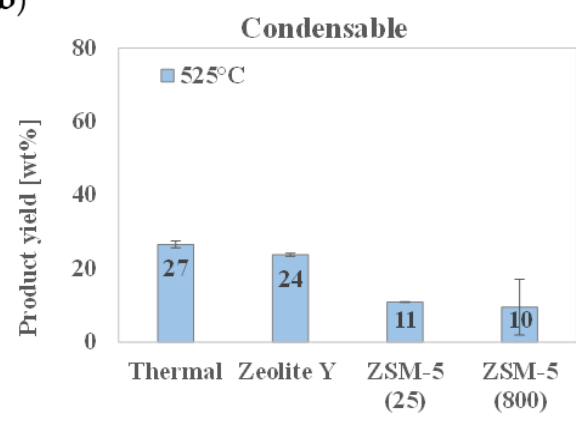

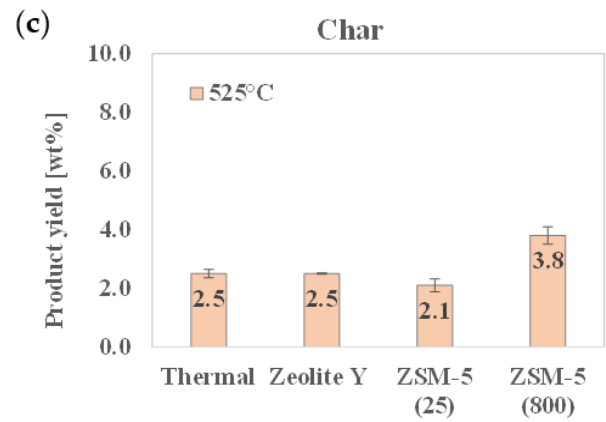

Figure 2. Product distribution following HDPE polymer decomposition in the presence of catalysts at $525{ }^{\circ} \mathrm{C}$. Si / $\mathrm{Al}$ ratios of the catalysts are depicted in brackets. (a) Gas yields. (b) Condensable yields. (c) Char yields. (Note: $y$-axis scale ranges are different).

Under thermal pyrolysis conditions, increasing the reaction temperature from $450{ }^{\circ} \mathrm{C}$ to $525{ }^{\circ} \mathrm{C}$ promoted conversions to gas ( $\sim 30 \mathrm{wt} \%$ to $\left.\sim 70 \mathrm{wt} \%\right)$ and reduced condensable yields ( $\sim 65 \mathrm{wt} \%$ to $\sim 30 \mathrm{wt} \%)$. Catalytic pyrolysis resulted in higher decomposition efficiency than thermal pyrolysis, as evidenced by higher gas yields. Higher gas yields correlated with lower condensable yields, indicating that the zeolites promoted secondary decomposition of the condensable vapors. Char yields (3-4 wt\%), representing the waste product, confirmed that pyrolysis resulted in 25 - to 30 -fold reduction in solid waste mass. No significant differences in waste minimization were observed at the different conditions.

The highest conversions to gas were obtained over ZSM-5(25) ( 90 wt\%). Zeolite Y or ZSM-5(800) enhanced gas yields to similar extents ( $50 \mathrm{wt} \%)$, whereas only $\sim 30 \mathrm{wt} \%$ gas yield was obtained without the addition of a catalyst. The two ZSM- 5 catalysts share similar structures and pore sizes, but differ in their $\mathrm{Si} / \mathrm{Al}$ ratios (25 vs. 800). Si/ Al ratios are inversely correlated with the catalyst acidity and polymer decomposition efficiency [14], supporting that this difference accounts for the higher decomposition efficiency achieved over ZSM-5(25) at $450{ }^{\circ} \mathrm{C}$.

Increasing the reaction temperature to $525^{\circ} \mathrm{C}$ (Figure 2), increased gas conversions for all treatments, except for treatment over ZSM-5(25). In the case of the latter, which was proven as highly efficient at $450{ }^{\circ} \mathrm{C}$, increasing temperature was not beneficial as no further improvement in polymer decomposition was observed. At a reaction temperature of $525^{\circ} \mathrm{C}$ (Figure 2), Catalytic pyrolysis conditions over zeolite Y resulted in similar product distributions as obtained by thermal pyrolysis, while catalytic pyrolysis over each of the two ZSM-5 zeolites resulted in slightly higher gas yields ( 10 wt\%).

Comparing the structural and chemical properties of zeolite $\mathrm{Y}$ and ZSM-5 showed that they have similar surface areas (Table 1). Zeolite Y has a lower Si / Al ratio than ZSM-5, and thus is more acidic, suggesting it may have better catalytic performance [15]. Nevertheless, ZSM-5 has smaller pores $(0.55 \mathrm{~nm})$ than zeolite $\mathrm{Y}(0.74 \mathrm{~nm})$, which likely accounts for their improved catalytic performance by allowing the access and breakdown of smaller molecules, in accordance with previous studies $[14,16]$. 


\subsection{Impact of Catalyst Loadings}

To study the effects of the catalyst loading (i.e., catalyst to polymer ratio) on the decomposition efficiency, HDPE was pyrolyzed over various catalyst to polymer ratios ranging from 0.05 to 0.2 . This set of experiments was focused on catalytic pyrolysis treatments over ZSM-5(25), since it resulted in the highest polymer decomposition efficiency. Experiments were performed at a reaction temperature of $450{ }^{\circ} \mathrm{C}$, since increasing the temperature in the presence of this catalyst did not yield significantly higher gas conversions. Product conversions into gas, condensable, and char of pyrolyzed HDPE over different catalyst loadings are presented in Figure 3. Higher catalyst loading resulted in increased polymer decomposition, as depicted by elevated gas conversions, ranging from $\sim 75 \mathrm{wt} \%$ to $95 \mathrm{wt} \%$. Higher gas yields correlated with lower condensable yields, and no significant differences in char yields were obtained. Condensable yields were nearly eliminated ( 2 wt $\%)$ by pyrolyzing HDPE over ZSM-5(25) and catalyst to polymer ratio of 0.2. Due to the efficient decomposition resulting from catalyst to polymer ratios of 0.1 and 0.2 , these ratios were chosen for further testing.

(a)

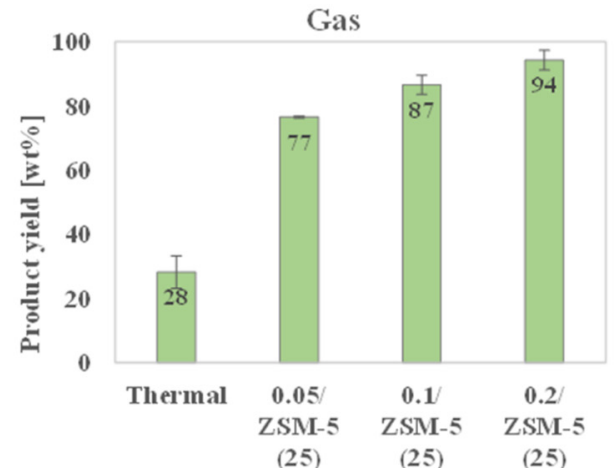

(b)

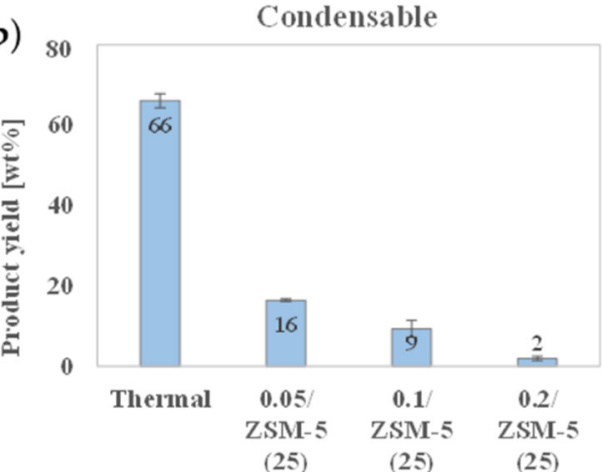

(c)

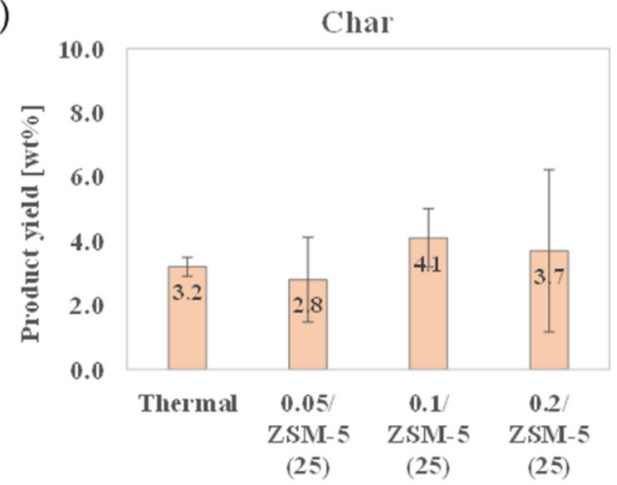

Figure 3. Effect of catalyst to polymer ratios on product distribution in the decomposition of HDPE at $450{ }^{\circ} \mathrm{C}$. Si / $\mathrm{Al}$ ratios of the catalysts are depicted in brackets. (a) Gas yields. (b) Condensable yields. (c) Char yields. (Note: $y$-axis scale ranges are different).

\subsection{Thermogravimetric Analysis: Onset of Decomposition and Reaction Rate}

Preliminary thermogravimetric tests were carried out on the macro-thermobalance with polyethylene and zeolite Y. Figure 4 shows the mass loss and decomposition rates over time, of either $5 \mathrm{~g}$ or $20 \mathrm{~g}$ of HDPE, with or without the addition of the catalyst. In accordance with the results obtained on the laboratory decomposition system, for both $5 \mathrm{~g}$ and $20 \mathrm{~g}$ of HDPE loads, the pyrolysis initiation temperature was significantly decreased in the presence of the catalyst. In the case of treating $5 \mathrm{~g}$ of $\mathrm{HDPE}$, the use of $10 \%$ of zeolite $\mathrm{Y}$ lowered the initial decomposition temperature of the pyrolysis from $475{ }^{\circ} \mathrm{C}$ to $430{ }^{\circ} \mathrm{C}$, whereas treatment of $20 \mathrm{~g}$ of HDPE, with the same catalyst loading, lowered the initial decomposition temperature from $485^{\circ} \mathrm{C}$ to $390{ }^{\circ} \mathrm{C}$. However, lower weight loss rates were 
obtained in the presence of the zeolite, according to the DTG curves (Figure 4c). Zeolite $\mathrm{Y}$ therefore acts as a catalyst by lowering the activation energy of the overall pyrolysis reaction, resulting in decomposition at lower reaction temperatures and reduced energy consumption. On the other hand, this impact is accompanied by a significant drop in the overall reaction rate.

(a)

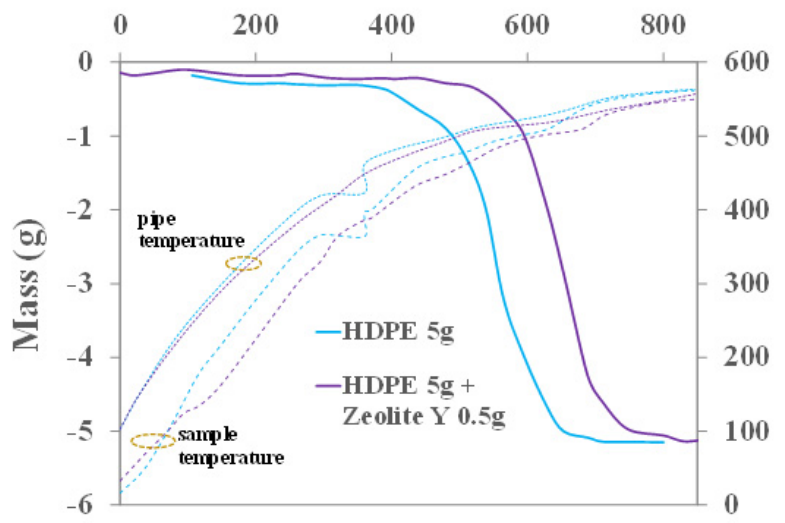

(b)

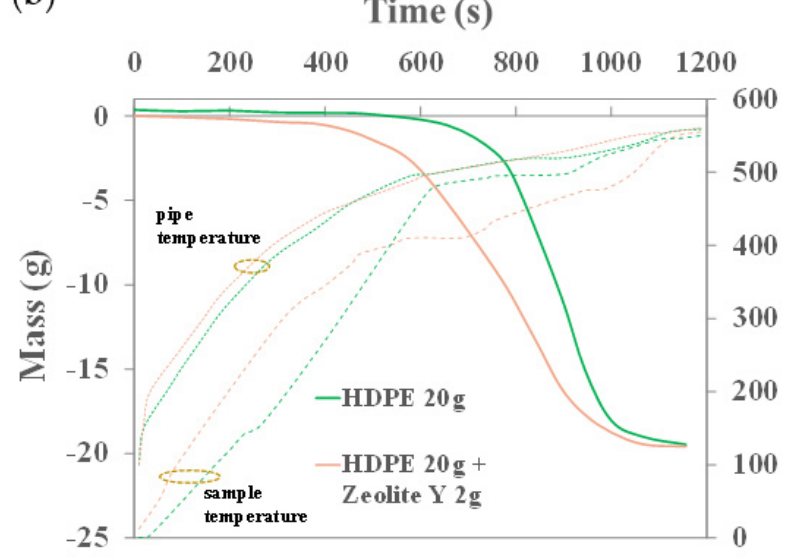

(c)

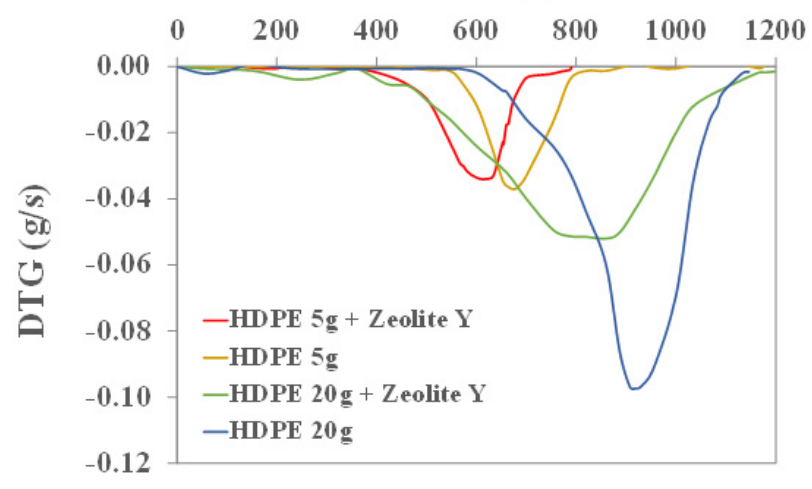

Figure 4. TGA and DTG curves of HDPE pyrolysis performed with and without zeolite Y. (a) TGA curves for $5 \mathrm{~g}$ of HDPE. (b) TGA curves for $20 \mathrm{~g}$ of HDPE. (c) DTG curves for $5 \mathrm{~g}$ and $20 \mathrm{~g}$ of HDPE.

Tests were carried out on different types of ZSM- 5 zeolites for different masses of HDPE ( $5 \mathrm{~g}$ and $20 \mathrm{~g}$ ) and different catalyst loadings ( 0.1 and 0.2 catalyst to polymer ratios). Figures 5 and 6 show the mass loss over time or temperature for the treatment of $5 \mathrm{~g}$ or $20 \mathrm{~g}$ of HDPE with different ZSM-5 catalysts, respectively. As was observed for Zeolite Y, all ZSM-5 zeolites lowered the pyrolysis temperature. The most predominant effect was obtained with ZSM- 5 with a $\mathrm{Si} / \mathrm{Al}$ ratio of 25 , which reduced the initiation temperature by $120^{\circ} \mathrm{C}$ on average. Pyrolysis kinetics were slowed down over the zeolites ZSM-5 (25) and ZSM-5 (200) (Figure 7). However, for ZSM-5 (800) the effect was reversed as pyrolysis rates increased at a catalyst loading of 0.2. These results can be explained by differences in sorption/desorption kinetics of pyrolysis gases over zeolites with different $\mathrm{Si} / \mathrm{Al}$ ratios. Previous studies showed that increased $\mathrm{Si} / \mathrm{Al}$ ratio content is associated with a reduced specific surface area of the zeolites as well as lower gas adsorption properties [17]. This can explain the dual impact of the zeolites, depending on their differences in $\mathrm{Si} / \mathrm{Al}$ ratios. Zeolites with a lower $\mathrm{Si} / \mathrm{Al}$ ratio yield higher surface reactivity in gas-solid processes, and hence result in a more prominent decrease in the overall activation energy of the pyrolysis reaction. On the other hand, lower $\mathrm{Si} / \mathrm{Al}$ ratio also result in limited gas desorption (higher retention properties) and therefore in slightly slower decomposition rates. 
(a) ZSM-5 (25)

Time (s)

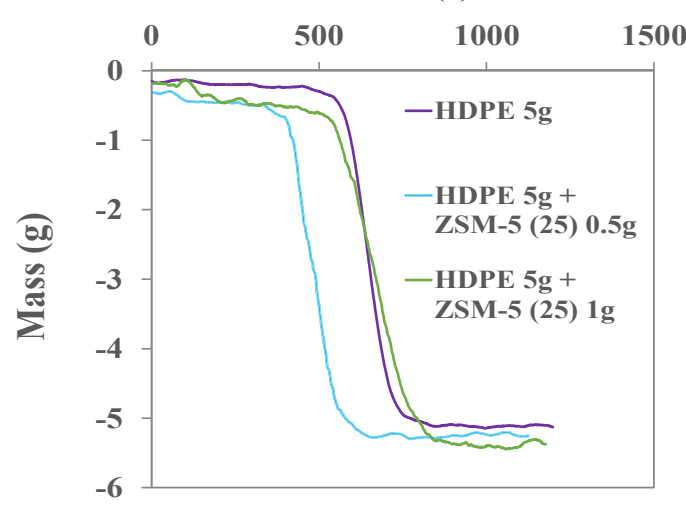

(b)

$$
\text { ZSM-5 (200) }
$$

Time (s)

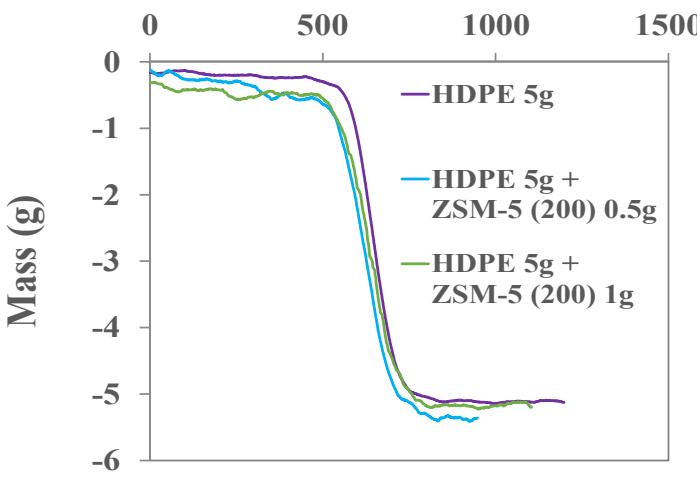

(c)

$$
\text { ZSM-5 (800) }
$$

Time (s)

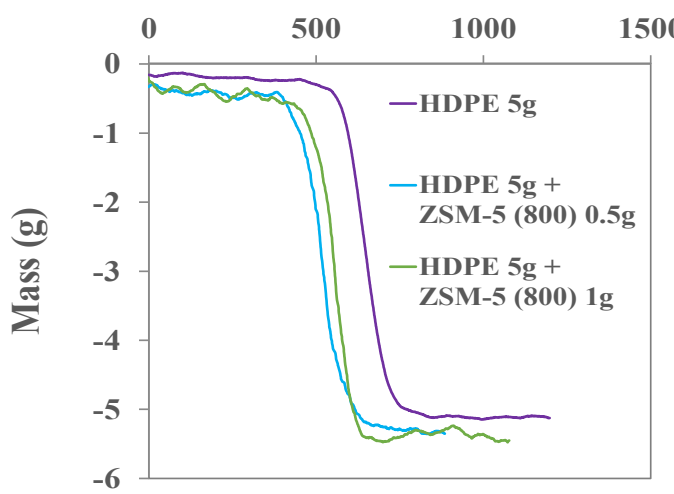

ZSM-5 (25)

Temperature $\left({ }^{\circ} \mathrm{C}\right)$

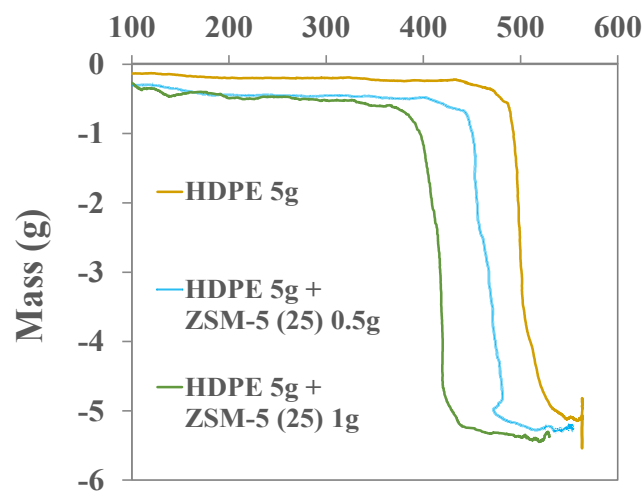

ZSM-5 (200)

Temperature $\left({ }^{\circ} \mathrm{C}\right)$

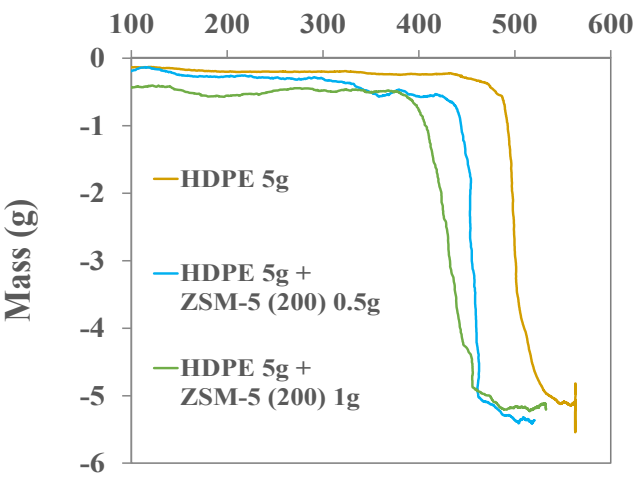

ZSM-5 (800)

Temperature $\left({ }^{\circ} \mathrm{C}\right)$

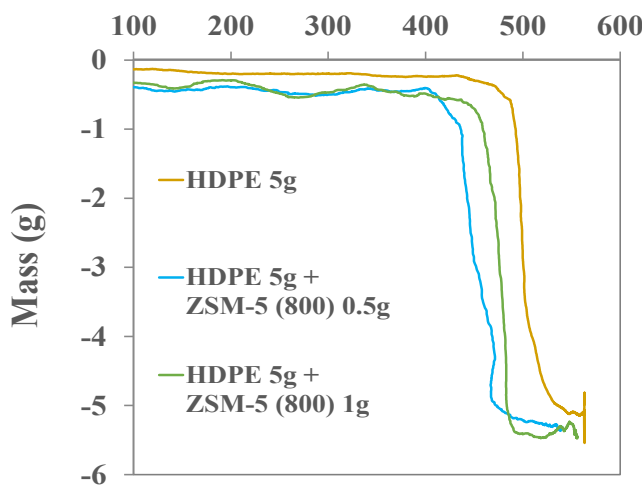

Figure 5. TGA curves of $5 \mathrm{~g}$ of HDPE pyrolysis performed with and without ZSM- 5 catalysts (different grades). (a) ZSM-5 (25). (b) ZSM-5 (200). (c) ZSM-5 (800). 
(a) ZSM-5 (25)

Time (s)

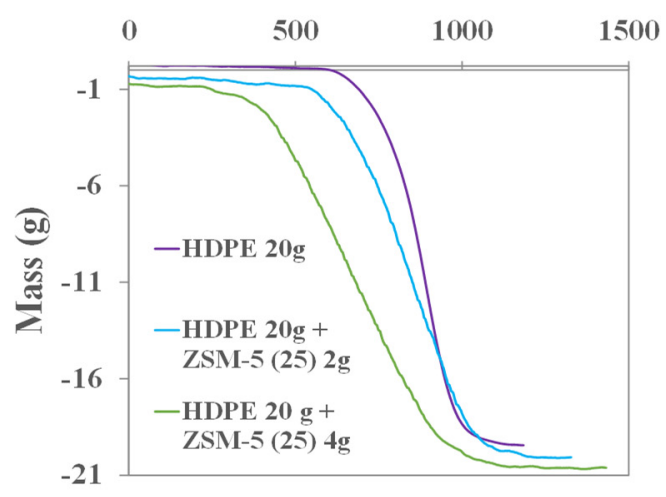

(b)

ZSM-5 (200)

Time (s)

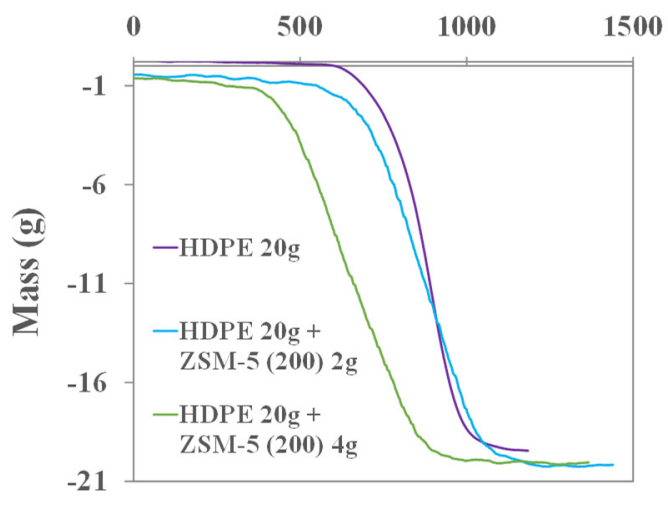

(c) ZSM-5 (800)

Time (s)

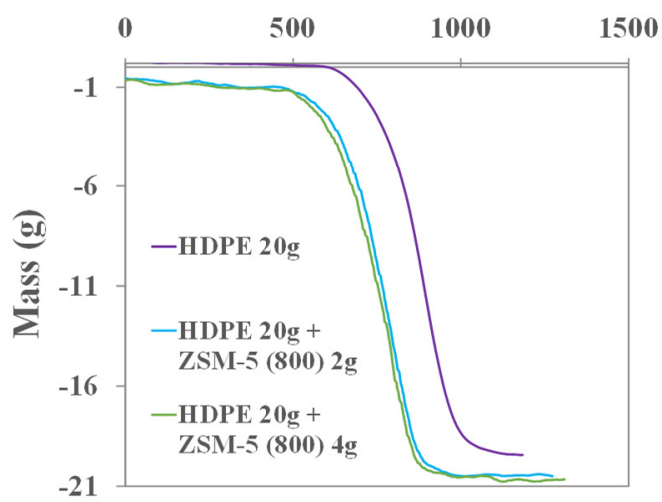

ZSM-5 (25)

Temperature $\left({ }^{\circ} \mathrm{C}\right)$

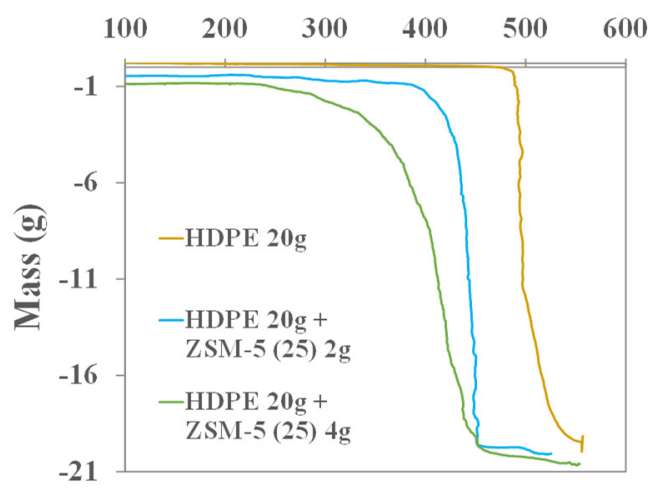

ZSM-5 (200)

Temperature $\left({ }^{\circ} \mathrm{C}\right)$

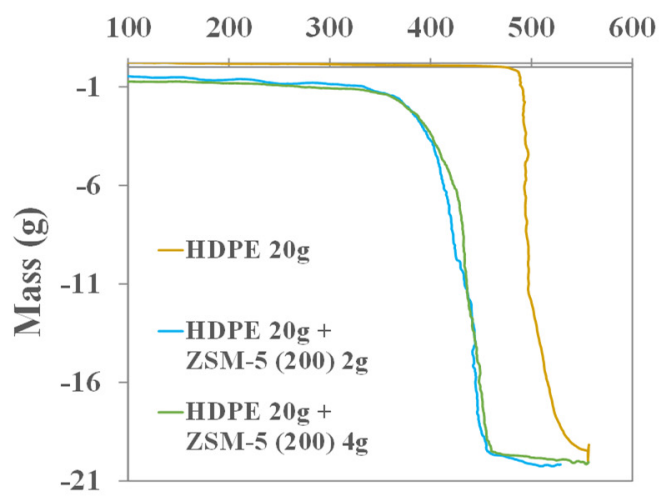

ZSM-5 (800)

Temperature $\left({ }^{\circ} \mathrm{C}\right)$

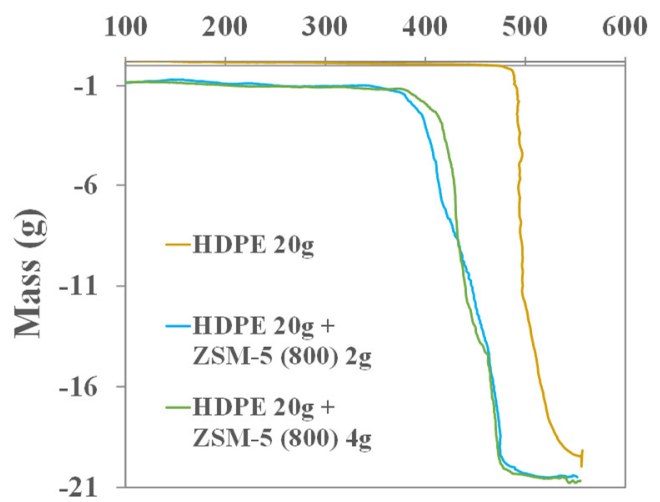

Figure 6. TGA curves of $20 \mathrm{~g}$ of HDPE pyrolysis performed with and without ZSM-5 catalysts (different grades). (a) ZSM-5 (25). (b) ZSM-5 (200). (c) ZSM-5 (800). 
(a)

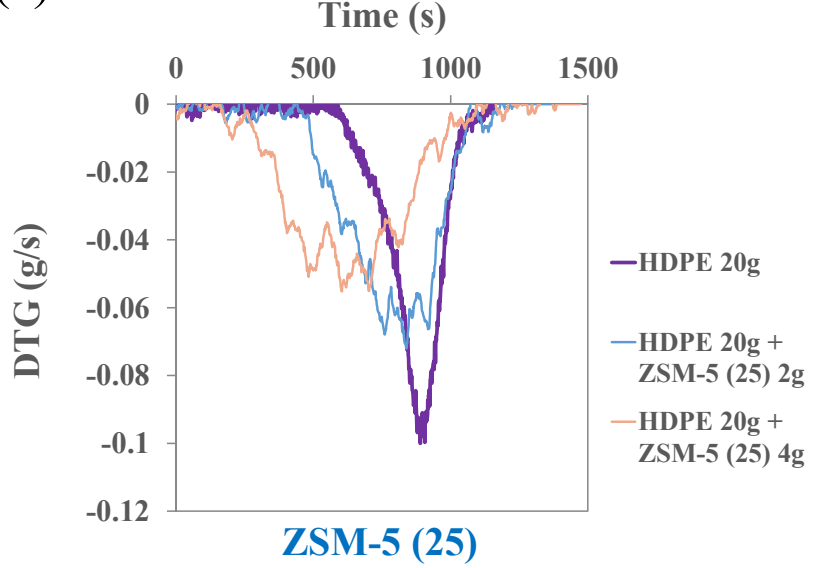

(b)

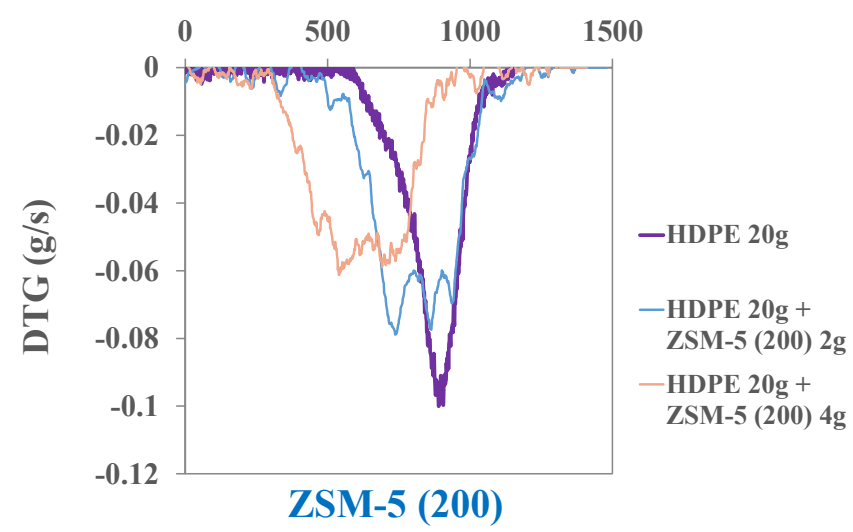

Time (s)

(c)

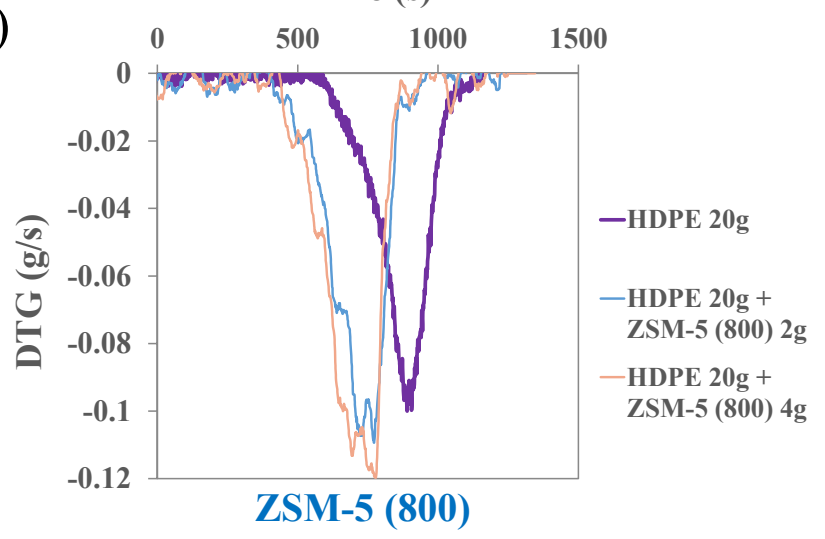

Figure 7. DTG curves of $20 \mathrm{~g}$ of HDPE pyrolysis performed with and without ZSM-5 catalysts (different grades). (a) ZSM-5 (25). (b) ZSM-5 (200). (c) ZSM-5 (800).

\section{Materials and Methods}

\subsection{Materials}

HDPE was supplied by Metzerplas Ltd. (Kibbutz Metzer, Israel) and shredded to $5 \mathrm{~mm}$ flakes. Zeolite $\mathrm{Y}\left(\mathrm{SiO}_{2} / \mathrm{Al}_{2} \mathrm{O}_{3}\right.$ molar ratio $\left.=5.1\right)$ and $\mathrm{ZSM}-5$ catalysts with different $\mathrm{SiO}_{2} / \mathrm{Al}_{2} \mathrm{O}_{3}$ molar ratios $(25,200$ and 800 ) were produced by Zeolyst (Conshohocken, PA, USA). Chemical and physical properties of the catalysts were provided by the manufacturer and are shown in Table 1.

\subsection{Laboratory-Scale Pyrolysis System, Experimental Conditions and Product Conversion}

Pyrolysis treatments and product conversion analysis were performed using the previously described laboratory-scale system [13] with minor modifications described herein (Figure 8). Briefly, the experimental system consisted of a quartz tubular reactor (550 $\mathrm{mm}$ long with a diameter of $60 \mathrm{~mm}$ ) positioned in a temperature-controlled electric oven and a cooled glass trap for condensable. Two thermocouples were placed in the system. The first was located in the cooled glass trap and the second inside the reactor near the sample. In each experiment, a blend of the HDPE polymer $(5.0 \mathrm{~g})$ and the catalyst $(0.5$, 1.0 or $2.0 \mathrm{~g}$ ) was manually mixed and placed in the reactor for the thermal treatment. To eliminate oxygen from the system prior to the thermal treatment, nitrogen was purged into the reactor at a rate of 200 standard $\mathrm{cc} / \mathrm{min}(\mathrm{sccm})$ for one hour. Then, the nitrogen flow rate was set to a rate of $20 \mathrm{sccm}$ and the oven was heated at a rate of $20^{\circ} \mathrm{C} / \mathrm{min}$. The oven was kept at a constant temperature for $180 \mathrm{~min}$ after reaching the target temperature $\left(450{ }^{\circ} \mathrm{C}\right.$ or $525^{\circ} \mathrm{C}$ depending on the experiment). A list of the experiments performed on the pyrolysis system is given in Table 2. It should be noted that a low inert gas flow rate 
was used in order to enhance gas yields by increasing the residence time in the reactor and, in turn, promoting secondary reactions of the decomposition products. The actual temperature measured at the center of the reactor was $25^{\circ} \mathrm{C}$ higher than the set-point (e.g., $475{ }^{\circ} \mathrm{C}$ when set to $450{ }^{\circ} \mathrm{C}$ ). Solid and liquid products were collected and weighed after the reactor cooled down. Char and condensable yields were calculated based on their post-treatment mass, relative to the initial polymer mass, while the gas yields were calculated according to the mass balance. All experiments were repeated at least twice and their average and standard deviation (less than $6 \%$ between replicates) are presented.
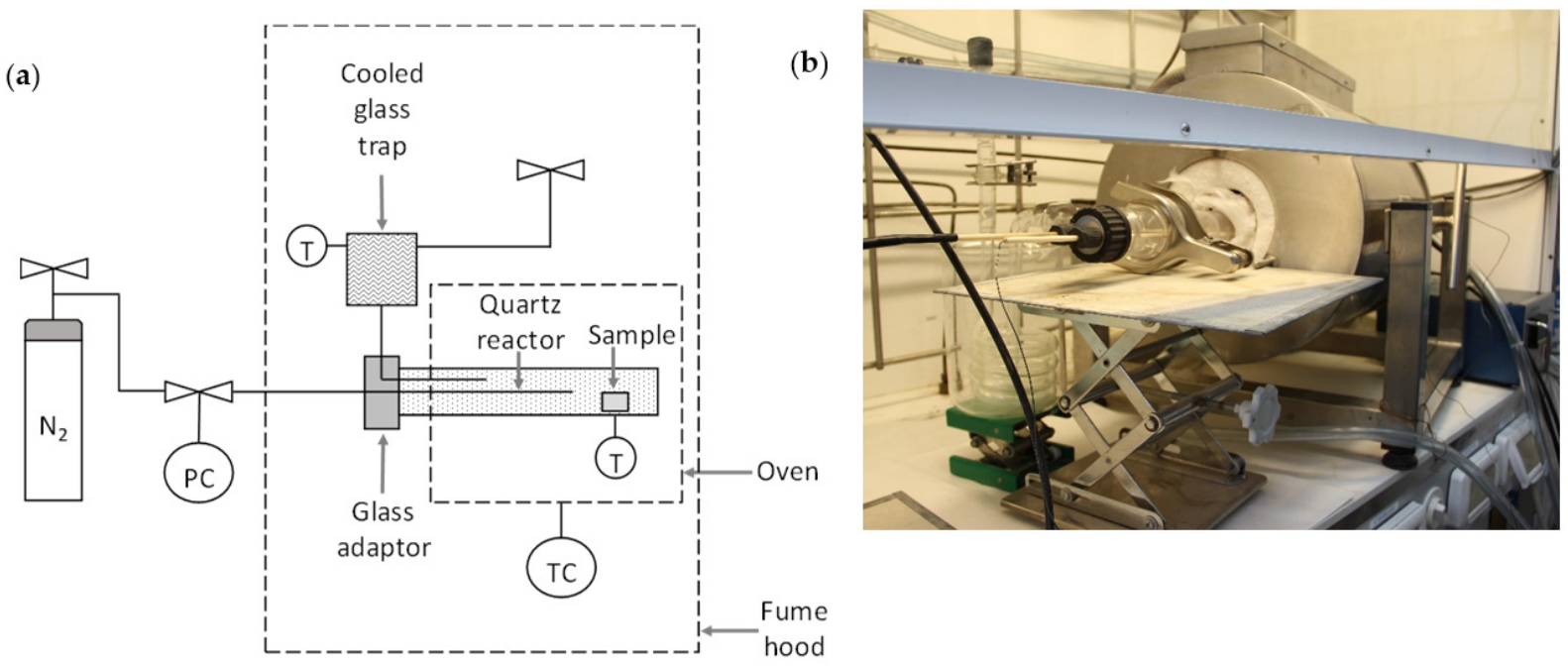

Figure 8. The laboratory-scale pyrolysis system. (a) A schematic diagram of the system. (b) A picture of the system.

Table 2. Experiments carried out on the pyrolysis system.

\begin{tabular}{cccc}
\hline $\begin{array}{c}\text { Reaction } \\
\text { Temperature }\end{array}$ & $\begin{array}{c}\text { HDPE } \\
\text { Mass }\end{array}$ & $\begin{array}{c}\text { Catalyst } \\
\left(\mathbf{S i O}_{\mathbf{2}} / \mathbf{A l}_{\mathbf{2}} \mathbf{O}_{\mathbf{3}} \text { Ratio) }\right.\end{array}$ & $\begin{array}{c}\text { Catalyst } \\
\text { Loading }\end{array}$ \\
\hline \multirow{3}{*}{$450^{\circ} \mathrm{C}$} & $5 \mathrm{~g}$ & No catalyst added & - \\
& & Zeolite Y (5.1) & $0.5 \mathrm{~g}$ \\
& & ZSM-5 (25) & $0.5 \mathrm{~g}$ \\
& & ZSM-5 (800) & $0.5 \mathrm{~g}$ \\
\hline \multirow{2}{*}{$525^{\circ} \mathrm{C}$} & \multirow{2}{*}{$\mathrm{g}$} & No catalyst added & - \\
& & Zeolite Y (5.1) & $0.5 \mathrm{~g}$ \\
& \multirow{2}{*}{$5 \mathrm{~g}$} & ZSM-5 (25) & $0.5 \mathrm{~g}$ \\
& & ZSM-5 (800) & $0.5 \mathrm{~g}$ \\
\hline \multirow{2}{*}{$450{ }^{\circ} \mathrm{C}$} & & ZSM-5 (25) & $0.25 \mathrm{~g}$ \\
& & ZSM-5 (25) & $1.0 \mathrm{~g}$ \\
\hline
\end{tabular}

\subsection{Macro-Thermogravimetric System, Experimental Conditions and Analysis}

Thermogravimetric analysis was performed using the DANTE experimental device [18] shown in Figure 9. The large capacity thermobalance was equipped with a camera, to observe phenomena that may affect the measurements, and multiple thermal sensors that do not impact the weighing. The complete setup included a $1500 \mathrm{~mm}$ long Haynes 214 alloy tube, $155 \mathrm{~mm}$ in diameter, which can be heated by a furnace up to $1200{ }^{\circ} \mathrm{C}$; a crucible containing the sample suspended from a hollow alumina rod, through which a thermopile (with up to eight thermocouples) was connected to a load cell in the upper chamber; an array of 13 thermocouples in the lower part of the furnace, arranged in the shape of a cross to measure the temperature in different locations; an isolation valve separating the atmospheres in the upper chamber and the furnace; and a gas treatment 
system to cool and clean the gaseous effluents of the heat treatment processes under study. The upper chamber was high enough $(1350 \mathrm{~mm})$ to accommodate the rod and the sample before it was introduced into the furnace at a given temperature. The load cell (HBM SP4M, $5 \mathrm{~kg}$ ) was connected wirelessly to the acquisition system via a transponder, thus avoiding wire-related mechanical constraints. The furnace can be swept vertically at different rates with either air, nitrogen or oxygen. This setup has been calibrated and validated for studies of organic and inorganic materials [9].

(a)

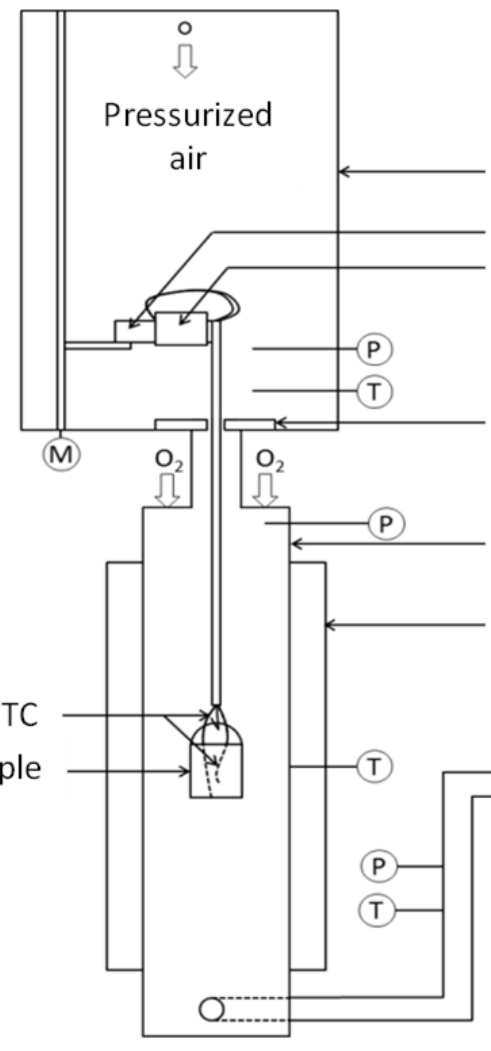

Airtight chamber

Load cell

Transpondeur

Sliding insulating unit

Haynes Tube

\section{Oven}

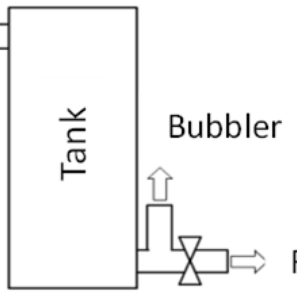

(b)

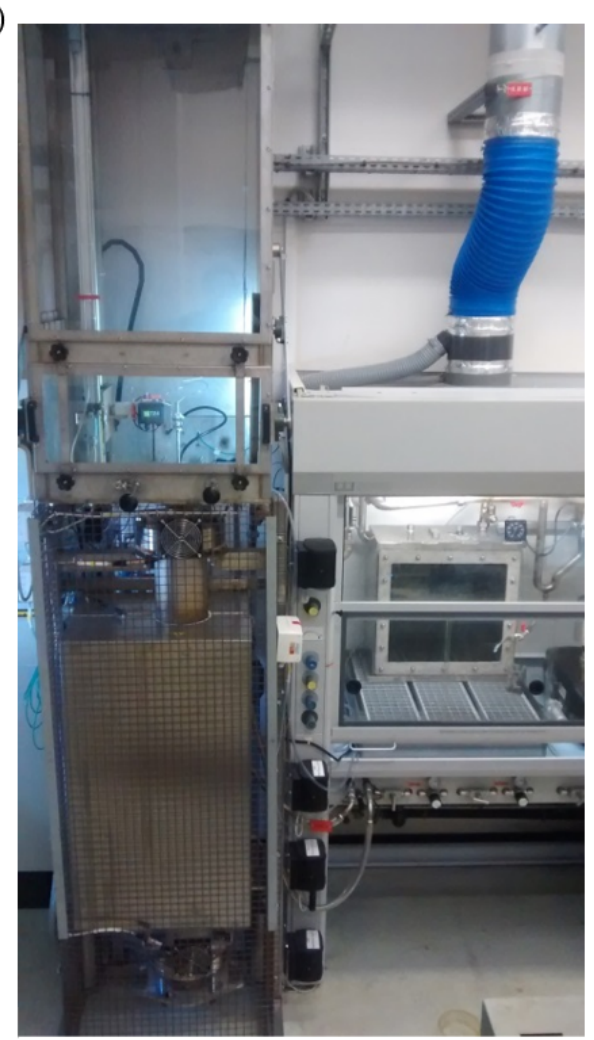

Figure 9. The DANTE macro-thermobalance. (a) A schematic diagram of the system. (b) A picture of the system.

The experimental system described above had to be adjusted to perform experiments under pyrolytic conditions. Thus, a special pyrolysis device consisting a stainless-steel enclosure was designed in order to ensure inert conditions around the sample (Figure 10). The device consisted a $12.5 \mathrm{~cm}$ high cylindric crucible (internal diameter $3.6 \mathrm{~cm}$ ), into which a tube was introduced in order to evacuate the pyrolysis gaseous products from the system without interfering with the internal organic charge. The oxygen circulating in the oven was required to allow the combustion of the pyrolysis gases leaving the device. Two thermocouples were placed in the device. The first was located inside the crucible, $100 \mathrm{~mm}$ from its upper part and the second was in the gas evacuation tube. Before introducing the polymer into the oven, the internal atmosphere of the device was inerted by the introduction of liquid nitrogen before sealing the unit. Once the temperature and pressure had stabilized in the thermobalance, the unit was lowered to the center of the oven. The tests were carried out under the following conditions: temperature in the furnace $670{ }^{\circ} \mathrm{C}$, pressure $-8 \mathrm{mbar}$, inerting gas (in the crucible) $\mathrm{N}_{2}$, gas in the furnace: $50 \mathrm{sccm}$ air and $150 \mathrm{sccm} \mathrm{O}_{2}$. Tests were carried out with $5 \mathrm{~g}$ and $20 \mathrm{~g}$ of polyethylene with and without catalyst. Different types of zeolitic catalysts were tested: zeolite $\mathrm{Y}$ and $\mathrm{ZSM}-5$ with different $\mathrm{SiO}_{2} / \mathrm{Al}_{2} \mathrm{O}_{3}$ ratios (25, 200,800 ) at different catalyst to polymer ratios of 0.1 and 0.2 . A list of the experiments performed on the DANTE macro-balance is given in Table 3. 
(a)

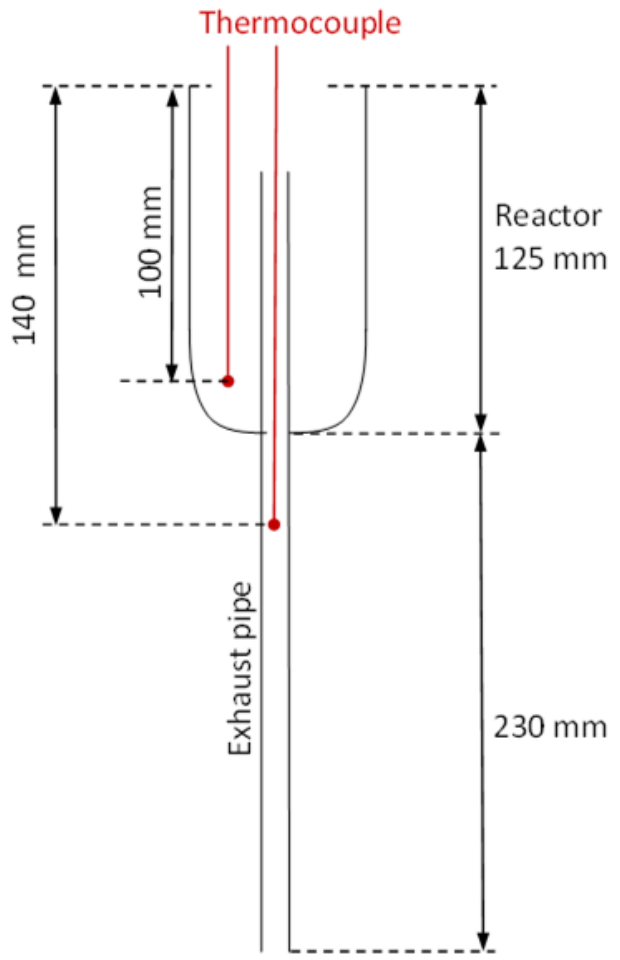

(b)

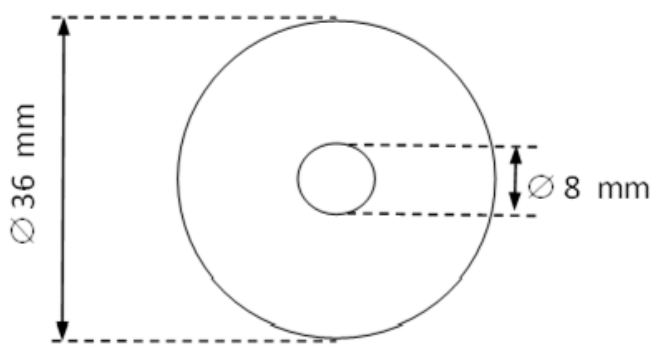

(c)

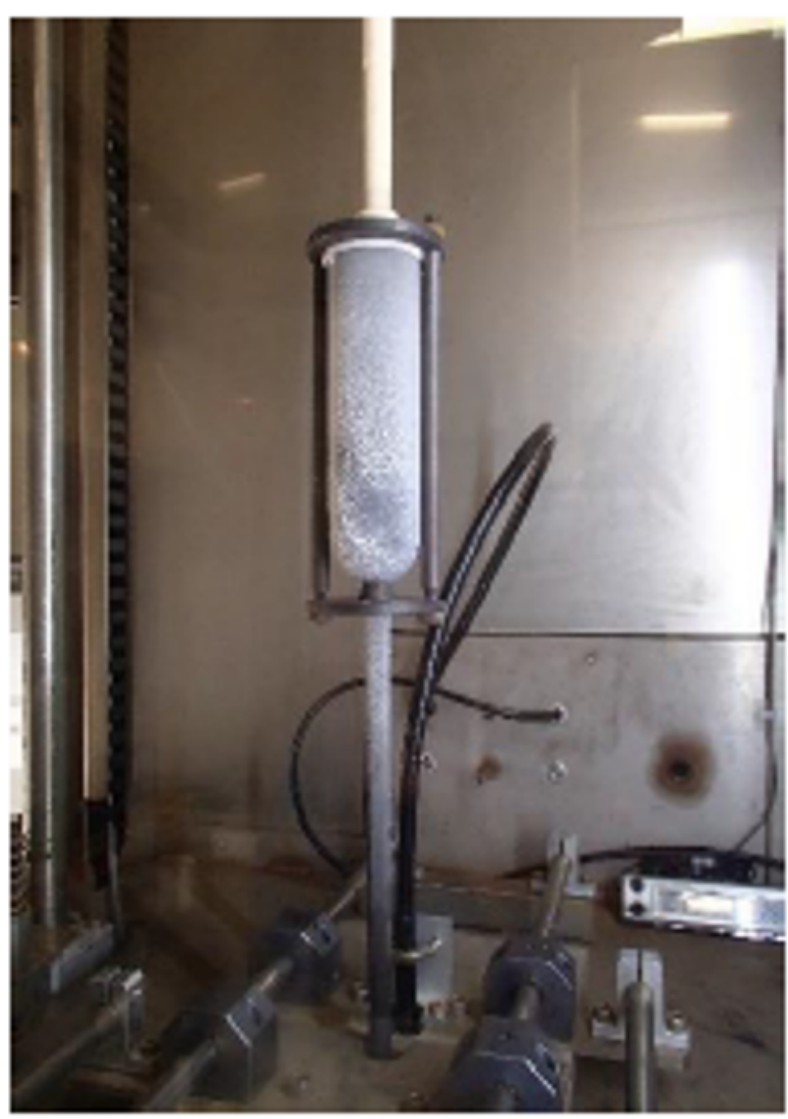

Figure 10. The pyrolysis device. (a) A schematic diagram of the reaction, profile view. (b) A schematic diagram of the reaction, upper view. (c) A picture and of the device.

Table 3. Experiments carried out on the DANTE macro-balance.

\begin{tabular}{ccc}
\hline $\begin{array}{c}\text { HDPE } \\
\text { Mass }\end{array}$ & $\begin{array}{c}\text { Catalyst } \\
\left(\mathbf{S i O}_{2} / \mathbf{A l}_{\mathbf{2}} \mathbf{O}_{3} \text { Ratio) }\right.\end{array}$ & $\begin{array}{c}\text { Catalyst } \\
\text { Loading }\end{array}$ \\
\hline & No catalyst added & - \\
Zeolite Y (5.1) & $0.5 \mathrm{~g}$ \\
ZSM-5 (25) & $0.5 \mathrm{~g}$ \\
ZSM-5 (25) & $1.0 \mathrm{~g}$ \\
ZSM-5 (200) & $0.5 \mathrm{~g}$ \\
ZSM-5 (200) & $1.0 \mathrm{~g}$ \\
& ZSM-5 (800) & $0.5 \mathrm{~g}$ \\
& ZSM-5 (800) & $1.0 \mathrm{~g}$ \\
\hline & No catalyst added & - \\
Zeolite Y (5.1) & $2.0 \mathrm{~g}$ \\
ZSM-5 (25) & $2.0 \mathrm{~g}$ \\
& ZSM-5 (25) & $4.0 \mathrm{~g}$ \\
& ZSM-5 (200) & $2.0 \mathrm{~g}$ \\
& ZSM-5 (200) & $4.0 \mathrm{~g}$ \\
& ZSM-5 (800) & $2.0 \mathrm{~g}$ \\
ZSM-5 (800) & $4.0 \mathrm{~g}$ \\
\hline
\end{tabular}




\section{Conclusions}

In the present study, the influence of two key parameters, the addition of catalysts and reaction temperatures, on polyethylene decomposition were studied to enhance gas conversions and reduce char and condensable yields. Of the catalysts tested, ZSM-5 (25) obtained the highest gas conversions at mild reaction temperatures. Both the addition of catalysts and increasing the reaction temperature were shown to enhance polymer decomposition, demonstrated by higher gas conversions. Either condition resulted in a substantial reduction of condensable yields while the char, representing the solid waste product, was not significantly affected. Reduction of the condensable yields can be further enhanced by increasing the ZSM- 5 catalyst loading up to a catalyst to polymer ratio of 0.2 .

Tests carried out on the DANTE macro-thermobalance allowed us to gain a closer insight into the reaction mechanism and kinetics, showing that adding ZSM-5 catalysts significantly decreased the pyrolytic decomposition temperature of polyethylene, which can possibly limit the energy consumption of such treatment. Among the zeolites tested, ZSM-5 (25) had the most significant impact on temperature reduction, which gives this zeolite an additional advantage. However, it was demonstrated that the use of this zeolite caused a twofold reduction in the kinetics of pyrolytic decomposition, probably due to a retention effect of the pyrolysis gases by limiting their desorption from the catalysts [17]. Additional studies could be undertaken in order to examine the solid-gas mechanisms involved in this process and to optimize the treatment parameters in order to find the best compromise between lowering treatment temperature and affecting the kinetics of pyrolysis.

Overall, ZSM-5(25) was identified as the most suitable catalyst for HDPE pyrolysis in terms of waste minimization (product composition) and energy consumption (treatment temperature).

Since the advantage provided by the catalysts at $450^{\circ} \mathrm{C}$ was "over-ridden" by increasing the reaction temperature to $525^{\circ} \mathrm{C}$, it is therefore recommended to decompose HDPE either in the presence of ZSM- 5 at $450{ }^{\circ} \mathrm{C}$ or without the catalyst at $525^{\circ} \mathrm{C}$. These two types of treatments present a tradeoff: adding the catalyst yields secondary waste, whereas operating at higher temperatures increases energy consumption and affects material selection and system design.

Author Contributions: Conceptualization, H.R.-A., O.K.-B., G.B.-N. and F.L.; methodology, J.S., F.R., N.B., S.G. and H.R.-A.; software, T.B.R.; validation, P.C. and F.L.; formal analysis, H.R.-A., T.B.R. and J.S.; writing—original draft preparation, H.R.-A. and F.L.; writing—review and editing, O.K.-B. and G.B.-N. All authors have read and agreed to the published version of the manuscript.

Funding: This work was supported by The Israel Atomic Energy Commission (IAEC) and The French Alternative Energies and Atomic Energy Commission (CEA).

Data Availability Statement: Data are contained within the article.

Conflicts of Interest: The authors declare no conflict of interest. The funders had no role in the design of the study; in the collection, analyses, or interpretation of data; in the writing of the manuscript, or in the decision to publish the results.

\section{References}

1. Nieminen, M.; Olin, M.; Laatikainen-Luntama, J.; Wickham, S.M.; Doudou, S.; Fuller, A.J.; Kent, J.; Fournier, M.; Clarke, S.; Scales, C.; et al. Thermal treatment for radioactive waste minimization. EPJ Nucl. Sci. Technol. 2020, 6, 25. [CrossRef]

2. Deckers, J. Incineration and plasma processes and technology for treatment and conditioning of radioactive waste. In Handbook of Advanced Radioactive Waste Conditioning Technologies, 1st ed.; Ojovan, M.I., Ed.; Woodhead Publishing: Cambridge, UK, 2011; pp. 43-66.

3. Qureshi, M.S.; Oasmaa, A.; Pihkola, H.; Deviatkin, I.; Tenhunen, A.; Mannila, J.; Minkkinen, H.; Pohjakallio, M.; Laine-Ylijoki, J. Pyrolysis of plastic waste: Opportunities and challenges. J. Anal. Appl. Pyrolysis 2020, 152, 104804. [CrossRef]

4. Jha, K.K.; Kannan, T.T.M. Recycling of plastic waste into fuel by pyrolysis-A review. Mater. Today Proc. 2021, 37, 3718-3720. [CrossRef] 
5. Armenise, S.; SyieLuing, W.; Ramírez-Velásquez, J.M.; Launay, F.; Wuebben, D.; Ngadi, N.; Rams, J.; Muñoz, M. Plastic waste recycling via pyrolysis: A bibliometric survey and literature review. J. Anal. Appl. Pyrolysis 2021, 158, 105265. [CrossRef]

6. Soni, V.K.; Singh, G.; Vijayan, B.K.; Chopra, A.; Kapur, G.S.; Ramakumar, S.S.V. Thermochemical Recycling of Waste Plastics by Pyrolysis: A Review. Energy Fuels 2021, 35, 12763-12808. [CrossRef]

7. Kremer, I.; Tomić, T.; Katančić, Z.; Hrnjak-Murgić, Z.; Erceg, M.; Schneider, D.R. Catalytic decomposition and kinetic study of mixed plastic waste. Clean Technol. Environ. Policy 2021, 23, 811-827. [CrossRef]

8. Kremer, I.; Tomić, T.; Katančić, Z.; Erceg, M.; Papuga, S.; Vuković, J.P.; Schneider, D.R. Catalytic pyrolysis of mechanically non-recyclable waste plastics mixture: Kinetics and pyrolysis in laboratory-scale reactor. J. Environ. Manag. 2021, $296,113145$. [CrossRef] [PubMed]

9. Miandad, R.; Barakat, M.A.; Aburiazaiza, A.S.; Rehan, M.; Nizami, A.S. Catalytic pyrolysis of plastic waste: A review. Process Saf. Environ. Prot. 2016, 102, 822-838. [CrossRef]

10. Ji, Y.; Yang, H.; Yan, Y. Strategies to Enhance the Catalytic Performance of ZSM-5 Zeolite in Hydrocarbon Cracking: A Review. Catalysts 2017, 7, 367. [CrossRef]

11. Chen, D.; Yin, L.; Wang, H.; He, P. Pyrolysis technologies for municipal solid waste: A review. Waste Manag. 2014, 34, $2466-2486$. [CrossRef] [PubMed]

12. Hu, D.H.; Chen, M.Q.; Huang, Y.W.; Wei, S.H.; Zhong, X.B. Evaluation on isothermal pyrolysis characteristics of typical technical solid wastes. Thermochim. Acta 2020, 688, 178604. [CrossRef]

13. Klein-BenDavid, O.; Peled, Y.; Tavor, D.; Ohaion, T.; Elias, P.; Bar-Nes, G. The pyrolysis and gasification of high-density polyethylene in a batch reactor. Waste Manag. Environ. VII 2014, 180, 77-87.

14. Manos, G.; Garforth, A.; Dwyer, J. Catalytic degradation of high-density polyethylene over different zeolitic structures. Ind. Eng. Chem. Res. 2000, 39, 1198-1202. [CrossRef]

15. Coelhoa, A.; Costaa, L.; Marquesc, M.M.; Fonsecab, I.M.; Lemosa, M.A.N.D.A.; Lemosa, F. The effect of ZSM-5 zeolite acidity on the catalytic degradation of high-density polyethylene using simultaneous DSC/TG analysis. Appl. Catal. A Gen. 2012, 413, 183-191. [CrossRef]

16. Seo, Y.H.; Lee, K.H.; Shin, D.H. Investigation of catalytic degradation of high-density polyethylene by hydrocarbon group type analysis. J. Anal. Appl. Pyrolysis 2003, 70, 383-398. [CrossRef]

17. Sethia, G.; Dangi, G.P.; Jetwani, A.L. Equilibrium and Dynamic Adsorption of Carbon Monoxide and Nitrogen on ZSM-5 with Different $\mathrm{SiO}_{2} / \mathrm{Al}_{2} \mathrm{O}_{3}$ Ratio. J. Sep. Sci. 2010, 45, 413-420. [CrossRef]

18. Balme, Q.; Lemont, F.; Rousset, F.; Sedan, J.; Charvin, P.; Bondroit, J.; Marias, F. Design, calibration and testing of a new macro-thermogravimetric analyzer. J. Therm. Anal. Calorim. 2018, 132, 1439-1447. [CrossRef] 